\title{
RESIDUES BEHAVIOR OF SOME HEAVY METALS DURING MANUFACTURING OF SOME MILK PRODUCTS
}

\author{
M. SAYED*, Z. ZAKY** and WALAA SHABAN* \\ *Department of Food Hygiene, Faculty of Veterinary Medicine, Assiut University, Egypt. \\ Corresponding author: dr.mohammedsayed@yahoo.com \\ ${ }^{* * *}$ Department of Forensic Medicine and Toxicology, Faculty of Veterinary Medicine, Assiut \\ University, Egypt.
}

\section{ABSTRACT}

Received at: $31 / 3 / 2012$

Accepted: 23/4/2012
This investigation was run to study the residue behavior of some heavy metals during manufacturing of some milk products. Samples of buffalo's milk as well as some milk products manufactured from it were analyzed for evaluation their contents of some metals that represents in 5 elements: manganese $(\mathrm{Mn})$, copper $(\mathrm{Cu})$, nickel $(\mathrm{Ni})$, magnesium $(\mathrm{Mg})$ and iron $(\mathrm{Fe})$. The buffalo's milk was obtained from a dairy shop located in Assiut city, Egypt, while the manufactured milk products were represented in cream, butter, ghee and Kareish cheese. Before manufacturing of milk products, milk was divided into 2 portions; the first as control for estimation and the second was added by standards of the investigated metals in a concentration of $1 \mathrm{ppm}$. All samples were digested and analyzed using ZEEnit 700P Atomic Absorption Spectrophotometer. The obtained results showed that the milk contents of $\mathrm{Mn}, \mathrm{Cu}, \mathrm{Ni}, \mathrm{Mg}$ and $\mathrm{Fe}$ were at concentrations of $2.3,0.7,0.07,0.01$ and $2.14 \mathrm{mg} / \mathrm{kg}$, respectively. With viewing to the recorded limits of International Dairy Federation (IDF), $\mathrm{Mn}, \mathrm{Cu}$ and $\mathrm{Fe}$ were found to exceed these limits. Mn was found to disappear from fat concentrated milk products (cream, butter and ghee), while concentrated in their by-products. $\mathrm{Cu}$ concentrated in cream and butter. Ni disappeared in ghee but concentrated in Kareish cheese. No obvious concentration of $\mathrm{Mg}$ in milk products while Fe concentrated in by-products skim milk, butter milk and whey. Although milk products contained more total metals content like in cream $(3.502 \mathrm{mg} / \mathrm{kg})$, butter $(3.64 \mathrm{mg} / \mathrm{kg})$ and ghee $(4.7712 \mathrm{mg} / \mathrm{kg})$ more than in the initial milk $(5.23 \mathrm{mg} / \mathrm{kg})$, the total metals content was more concentrated in by-products like in skim milk $(7.89 \mathrm{mg} / \mathrm{kg})$, butter milk $(7.6171 \mathrm{mg} / \mathrm{kg})$ and whey $(5.206 \mathrm{mg} / \mathrm{kg})$. But in case of Kareish cheese, it $(3.493 \mathrm{mg} / \mathrm{kg}$ ) contained total metals content lower than in initial milk. The public health significance of the examined metals, as well as, the recommended hygienic measures for human safety were discussed.

Key words: Milk, Milk products, Heavy metals, Manganese, Copper, Nickel; Magnesium, Iron. 


\section{سلوك بقايا بعض المعادن الثقيلة أثناء تصنيع بعض منتجات الألبان \\ محد سبل ، زكريا مختار زكي ، ولاء شعبان}

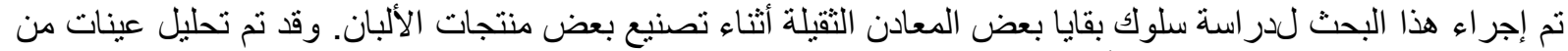

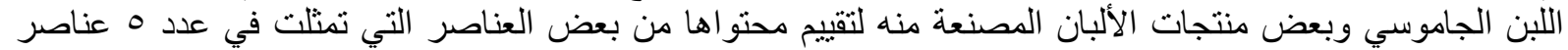

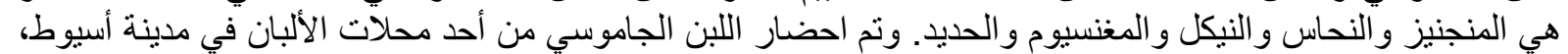

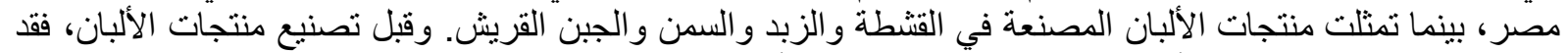

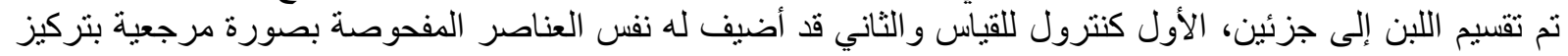

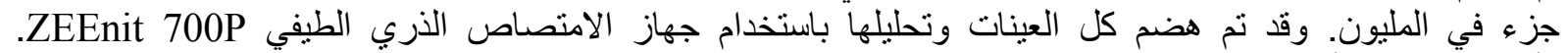
و أظهرت النتائج أن محتوى اللبن من عناصر المنجنيز و النحاس و النيكل و المغنسيوم والحديد كان بتركيز ات 0.07، 0.01، 2.14 مج/كجم، على الترنيب. وبالنظر إلى الحدود المسجلة لإتحاد الألبان الدولي (IDF) فإن المنجنيز و النحاس والحديد قد تخطى النسب المسموح بها. وقد وجد المنجنيز مختفيا من منتجات الألبان المركزة بالئ بالدسم (القشطة

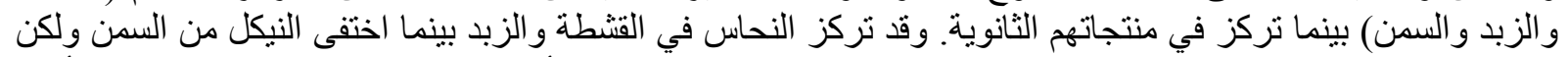
تركز في الجبن القريش، ولم يكن هناك تركيز واضح للمغنسيو فئن في في منتجات الألبان بينما تركز الحديد في منتجات الألبان

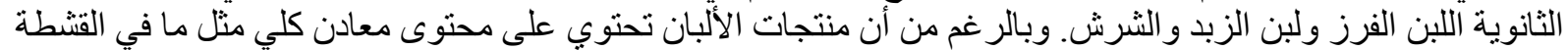

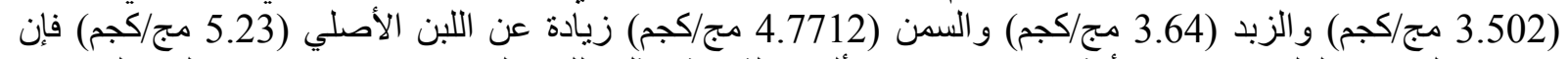

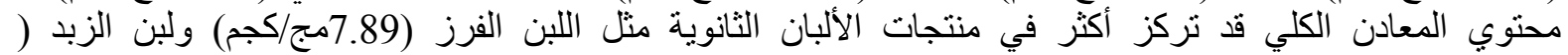

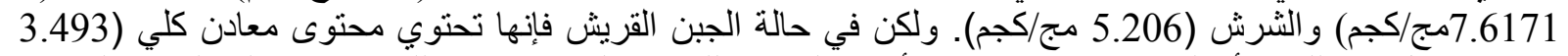

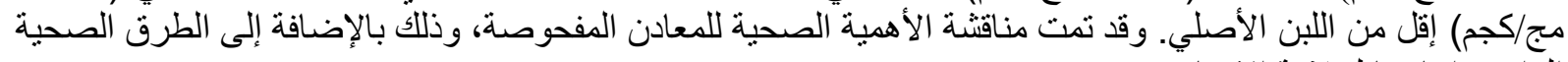
الواجب اتباعها لسلامة الإنسان.

الكلمات الكاشفة: اللبن، منتجات الألبان، المعادن الثقبلة، المنجنبز، النحاس، النبكل، المغنسبوم، الحدبد.

\section{INTRODUCTION}

Increase in industrial and agricultural processes have resulted in increased concentration of metals in the air, water and soil. These metals are taken in by plants and consequently accumulate in their tissues. Animals that graze on such contaminated plants and drink from polluted waters also accumulate such metals in their tissues and milk if lactating (Yahaya et al., 2010). A large amount of these metals taken in by plants and animals subsequently find their way into the food chain. This ever increasing pollution has given rise to concern on the intake of harmful metals in humans. Metals enter the human body through inhalation, ingestion or absorption through the skin (Ahmed, 2002; Ogabiela et al., 2010). The intake through ingestion depends on food habit.

Although metals are essential nutrients and have a variety of biochemical functions in all living organisms and important industrial uses, their potential toxicity to humans and animals is a source of concern. They can be toxic when taken in excess; both toxicity and necessity vary from element to element and from species to species (Tripathi et al., 1997). It is therefore necessary to monitor and control their levels in consumed food. The measurement of metal levels is helpful not only in ascertaining risk to human health but also in the assessment of environmental quality (Farid et al., 2004; Birghila et al., 2008). Many reports indicated heavy metals in milk and attributed the presence of these heavy metals in milk and dairy products to exposure of lactating cows to environmental pollution, consumption of contaminated feed stuffs and water as well as the production process. Some of these metals, such as $\mathrm{Cu}$, $\mathrm{Ni}, \mathrm{Mn}, \mathrm{Cr}$ and $\mathrm{Fe}$, for example are essential in very low concentration for the survival of all forms of life (Watson, 2001). Higher levels of $\mathrm{Cr}, \mathrm{Ni}$ and $\mathrm{Co}$ are toxic which released to the environment. They originated from dumping industrial wastes in the rivers, as well as the application of phosphate fertilizers (Venugopal and Luckey, 1978).

Abnormal accumulation of $\mathrm{Cu}$ in the tissues and blood is a point of similarity with genetic disease of man called Wilson's disease (Jones and Hunt, 1983; Lee and Garvey, 1998). Most 
absorbed $\mathrm{Cu}$ is stored in liver and bone marrow where it is bound to metallothionein (Sarkar et al., 1983), the acute exposure to $\mathrm{Cu}$ result in nausea, vomiting, bloody diarrhea, hypertension, uremia and cardiovascular collapse (Gossel and Bricker, 1990).

Toxicity of metal is closely related to age, sex, route and duration of exposure, level and frequency of intake, solubility, metal oxidation state, retention percentage, absorption rate and mechanisms/efficiency of excretion (Venugopal and Luckey, 1978; Fe.

Mertz, 1986).

Milk and milk products are the most diversified of the natural foodstuffs in terms of composition, contains more than 20 different trace elements. Most of them are essential and very important such as $\mathrm{Cu}, \mathrm{Zn}$, Mn and Fe (Schroeder, 1973; WHO, 1973; Somer, 1974). These metals are co-factors in many enzymes and play an important role in many physiological functions of man and animals. Lack of these metals causes disturbances and pathological conditions (Koh and Judson, 1986; Schuhmacher et al., 1991). The amount of metals in uncontaminated milk is admittedly minute, but their contents may be significantly altered through manufacturing and packaging process as well as metals that may be contaminate different cattle's feed and environment such as $\mathrm{Pb}, \mathrm{Cd}, \mathrm{Cr}, \mathrm{Ni}$ and $\mathrm{Co}$ could be excreted into milk at various levels (Abou-Arab et al., 1994; Abou-Arab, 1997) and causing serious problems.

Milk is known as an excellent source of $\mathrm{Ca}$, and it can supply moderate amounts of $\mathrm{Mg}$, smaller quantity of $\mathrm{Zn}$ and very small contents of $\mathrm{Fe}$ and $\mathrm{Cu}$ (Pennigton et al., 1995). On the other hand, due to the growing environmental pollution it is also necessary to determine and monitor the levels of toxic metals in milk, because they can significantly influence the human health (Steijns, 2001; Licata et al., 2004).

The presence of heavy metals in dairy products may be attributed to contamination of the original cow's milk, which may be due to exposure of lactating cow to environmental pollution or consumption of feeding stuffs and water (Carl, 1991; Okada et al., 1997). Moreover, raw milk may be exposed to contamination during its manufacture (Ukhun et al., 1990; El-Batanouni and Abo El- Ata, 1996).

The aim of this investigation was to follow up the residues behavior of metals in different milk products during their manufacturing process originated from buffalo's milk on the concentration levels of $\mathrm{Mn}, \mathrm{Cu}, \mathrm{Ni}, \mathrm{Mg}$ and

\section{MATERIALS and METHODS}

\section{Samples:}

I.1. Bulk milk: A total amount of $14 \mathrm{~kg}$ of market buffalo's milk was collected in a clean stockpot from a dairy shop in Assiut city, and then transferred to the laboratory with a minimum of delay. In the laboratory and after thoroughly mixing of the bulk milk, $4 \mathrm{~kg}$ was taken in another clean stockpot for control milk and milk products samples, and the rest $10 \mathrm{~kg}$ was taken for standard milk and milk products samples.

I.2. Control milk sample: After thoroughly mixing of the $4 \mathrm{~kg}$ milk, $1 \mathrm{ml}$ was taken as a control milk sample and the rest was subjected to the manufacture of some milk products.

\section{I.3. Control milk products and by-products} samples: The rest of $4 \mathrm{~kg}$ milk was thoroughly mixed and subjected to a separator; cream (product) and skim milk (byproduct) were obtained. The obtained cream was subjected to churner; butter (product) and butter milk (by-product) were obtained. Ghee (product) and morta (by-product) were obtained after subjection the obtained butter to a boiler. The obtained skim milk was subjected to rennet; Kareish cheese (product) and whey (by-product) were obtained. From each obtained milk product and by-product, 1 $\mathrm{g}$ and/or ml was taken as a control milk product sample or control milk by-product sample.

I.4. Standard milk sample: After thoroughly mixing of the previously separated $10 \mathrm{~kg}$ milk in its stockpot, $10 \mathrm{ml}(1000 \mathrm{mg} / \mathrm{L})$ of each of 
standard stock solutions of heavy metals (Merck, K GaA, 64271 Darmstadt, Germany) of manganese $(\mathrm{Mn})$, copper $(\mathrm{Cu})$, nickel $(\mathrm{Ni})$, magnesium $(\mathrm{Mg})$ and iron $(\mathrm{Fe})$ was added. That is means; $1 \mathrm{mg} / \mathrm{kg}$ of each metal was added to the milk (1 ppm). After thoroughly mixing of the milk with standards, $1 \mathrm{ml}$ was taken as a standard milk sample and the rest was subjected to the manufacture of some milk products.

I.5. Standard milk products and byproducts samples: The rest of $10 \mathrm{~kg}$ milk was subjected for obtaining milk products and by-products in the same way described before. From each obtained milk product and by-product, $1 \mathrm{~g}$ and/or $\mathrm{ml}$ was taken as a standard milk product sample or standard milk by-product sample.

\section{Manufacturing of milk products:}

II.1. Cream manufacture: It was manufactured through separation process using electrical separator (Alva-Laval, Germany). Before separation, milk was warmed and then separated to obtain cream and skim milk.

II.2. Butter manufacture: It was manufactured through churning process using electrical mixer (Moulinex). The aforementioned manufactured cream was churned to obtain butter and butter milk according to the method of Eckles et al. (1951).

II.3. Ghee manufacture: It was manufactured through boiling process. The aforementioned manufactured butter was boiled till conversation of butter into ghee and curd (morta) according to the method described by El-Sadek et al. (1972).

II.4. Kareish cheese manufacture: It was manufactured through addition of rennet to the aforementioned obtained skim milk. No salt was added to avoid any metals can be added from it.

\section{Preparation of the samples:}

All glassware were washed, before use with distilled water, soaked in nitric acid (30\%), then rinsed in redistilled water and air dried. The glassware was kept in clean place to avoid contamination. After that, each sample following weighing was transferred into a clean digestion flask, previously acid-washed then de-ionized water and dried. All digestion flasks were identified for examination.

\section{Digestion procedures of the samples:}

Each prepared sample was treated with $5 \mathrm{ml}$ nitric: perchloric acid mixture $\left(\mathrm{HNO}_{3}: \mathrm{HCLO}_{3}\right.$ $=4: 1 \mathrm{v} / \mathrm{v}$ ) as per Kolmer et al. (1951). The samples were left to be stand for the cold digestion overnight, then the samples were heated on the hot plate $1030(\mathrm{Ru}$ Mo $100 \mathrm{El}$ Basaten St. Cairo) at $70^{\circ} \mathrm{C}$ till dryness of the samples. Further addition of $5 \mathrm{ml}$ nitric : perchloric acid mixture $\left(\mathrm{HNO}_{3}: \mathrm{HCLO}_{3}=4: 1\right.$ $\mathrm{v} / \mathrm{v})$ to each sample was undertaken followed by heating again on the hot plate but at $50^{\circ} \mathrm{C}$ till the brown fumes of $\mathrm{NO}_{3}$ disappeared and the sample become clear. After cooling, each digest was diluted to $25 \mathrm{ml}$ with de-ionized water and filtered through ashless filter paper (Whatman). The clear filtrate of each sample was kept in refrigerator to avoid evaporation. A blank (without sample) was prepared in the same way.

\section{Metal analysis using Atomic Absorption Spectrophotometer:}

The metal analysis of the samples was carried out in the Central Laboratory of the Faculty of Veterinary Medicine; Assiut University, Egypt. All samples (controls and standards) in addition to the blank were analyzed for detection and/or measurement of $\mathrm{Mn}, \mathrm{Cu}, \mathrm{Ni}$ and $\mathrm{Mg}$ by using of ZEEnit 700P Atomic Absorption Spectrophotometer with Graphite Furnace Unite (AASG) (Perkin-Elmer Atomic Absorption Spectrophotometry model 2380, USA). While the measurement of Fe was done using flame Atomic Absorption Spectrophotometer.

VI. Quantitative determination of the studied heavy metals:

The concentration of $\mathrm{Mn}, \mathrm{Cu}, \mathrm{Ni}, \mathrm{Mg}$ and $\mathrm{Fe}$ in the examined samples was calculated according to the following equation:

$$
\mathrm{C}=\mathrm{R} \times \mathrm{D} / \mathrm{W}
$$

Where:

$\mathrm{C}=$ Concentration of heavy metal $(\mathrm{mg} / \mathrm{kg})$

wet weight (ppm) 
$\mathrm{R}=$ Reading of metal concentration on digital scale of Atomic Absorption

Spectrophotometer

$\mathrm{D}=$ Final volume of prepared sample in $\mathrm{ml}$

$\mathrm{W}=$ Weight of the wet sample

The contents of heavy metals were expressed as $\mathrm{mg} / \mathrm{kg}$ of the sample based on wet weight.
The concentration of absorbance values of heavy metals in the blank samples were also calculated and subtracted from each analyzed sample to exclude any traces of metals that might be present in the used acids for digestion.

\section{RESULTS}

Table 1: Some recorded metals content $(\mathrm{mg} / \mathrm{kg})$ in milk.

\begin{tabular}{|c|c|c|c|c|c|c|c|c|c|c|c|}
\hline \multirow{2}{*}{ Metal } & \multirow{2}{*}{$\begin{array}{c}\text { IDF } \\
(1979)\end{array}$} & \multirow{2}{*}{$\begin{array}{l}\text { Abou- } \\
\text { Arab } \\
(1991)\end{array}$} & \multicolumn{2}{|c|}{$\begin{array}{c}\text { El-Prince and } \\
\text { Sharkawy (1999) }\end{array}$} & \multirow{2}{*}{$\begin{array}{c}\text { Florea } \\
\text { et al. } \\
(2006)\end{array}$} & \multirow{2}{*}{$\begin{array}{l}\text { Birghila } \\
\text { et al. } \\
(2008)\end{array}$} & \multicolumn{2}{|c|}{ Enb et al. (2009) } & \multicolumn{2}{|c|}{$\begin{array}{l}\text { Ogabiela et al. } \\
\text { (2011) }\end{array}$} & \multirow{2}{*}{$\begin{array}{l}\text { The } \\
\text { present } \\
\text { study }\end{array}$} \\
\hline & & & Cow's & Buffalo's & & & Cow's & Buffalo's & $\begin{array}{l}\text { Cow's } \\
\text { (Kano } \\
\text { region) }\end{array}$ & $\begin{array}{l}\text { Cow's } \\
\text { (Zaria } \\
\text { region) }\end{array}$ & \\
\hline $\mathrm{Mn}$ & 0.025 & 0.06 & - & - & 0.051 & 0.08 & 0.047 & 0.072 & 0.179 & 0.219 & 2.30 \\
\hline $\mathrm{Cu}$ & 0.1 & 0.22 & 0.592 & 0.825 & 0.14 & 0.17 & 0.131 & 0.201 & 0.252 & 0.214 & 0.71 \\
\hline $\mathrm{Fe}$ & 0.37 & 0.95 & 0.428 & 0.322 & 0.97 & 0.72 & 0.572 & 0.880 & 5.99 & 3.24 & 2.14 \\
\hline
\end{tabular}

Table 2: The metals concentration $(\mathrm{mg} / \mathrm{kg})$ in the control samples.

\begin{tabular}{ccccccccccc}
\hline Metal & Milk & Cream & $\begin{array}{c}\text { Skim } \\
\text { milk }\end{array}$ & Butter & $\begin{array}{c}\text { Butter } \\
\text { milk }\end{array}$ & Ghee & Morta & $\begin{array}{c}\text { Kareish } \\
\text { cheese }\end{array}$ & Whey & Rennet \\
\hline $\mathrm{Mn}$ & 2.3 & 0 & 3.9 & 0 & 3.01 & 0 & 0.17 & 0.71 & 1.86 & 5.7 \\
\hline $\mathrm{Cu}$ & 0.71 & 0.986 & 0.64 & 1.04 & 0.59 & 0.86 & 2.06 & 0.99 & 0.92 & 22.9 \\
\hline $\mathrm{Ni}$ & 0.07 & 0.03 & 0.07 & 0.05 & 0.05 & 0 & 0 & 0.13 & 0.06 & 0.4 \\
\hline $\mathrm{Mg}$ & 0.01 & 0.016 & 0.03 & 0.01 & 0.0171 & 0.0012 & 0.004 & 0.033 & 0.016 & 1.6 \\
\hline $\mathrm{Fe}$ & 2.14 & 2.47 & 3.25 & 2.54 & 3.95 & 3.91 & 3.25 & 1.63 & 2.35 & 7.68 \\
\hline $\mathrm{T}$ & 5.23 & 3.502 & 7.89 & 3.64 & 7.6171 & 4.7712 & 5.484 & 3.493 & 5.206 & 38.28 \\
\hline
\end{tabular}




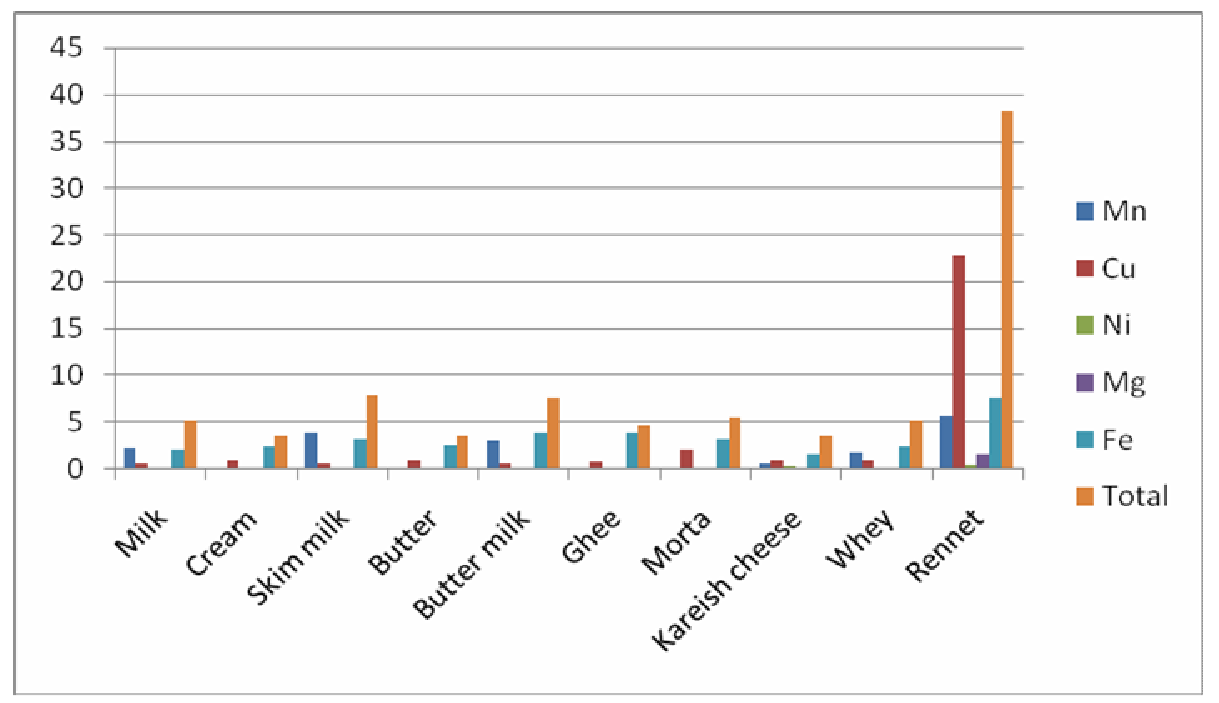

Figure 1: The metals concentration $(\mathrm{mg} / \mathrm{kg})$ in the control samples.

Table 3: The metals concentration $(\mathrm{mg} / \mathrm{kg})$ in the standards samples.

\begin{tabular}{ccccccccccc}
\hline Metal & Milk & Cream & $\begin{array}{c}\text { Skim } \\
\text { milk }\end{array}$ & Butter & $\begin{array}{c}\text { Butter } \\
\text { milk }\end{array}$ & Ghee & Morta & $\begin{array}{c}\text { Kareish } \\
\text { cheese }\end{array}$ & Whey & Rennet \\
\hline $\mathrm{Mn}$ & 3.26 & 0 & 4.50 & 0.497 & 6.78 & 0 & 0.37 & 7.03 & 2.59 & 5.7 \\
\hline $\mathrm{Cu}$ & 1.80 & 1.96 & 1.92 & 1.18 & 2.7 & 0.94 & 4.5 & 7.14 & 1.28 & 22.9 \\
\hline $\mathrm{Ni}$ & 0.15 & 0.08 & 0.20 & 0.07 & 0.22 & 0 & 0.01 & 0.24 & 0.143 & 0.4 \\
\hline $\mathrm{Mg}$ & 0.02 & 0.026 & 0.15 & 0.02 & 0.028 & 0.008 & 0.03 & 0.16 & 0.03 & 1.6 \\
\hline $\mathrm{Fe}$ & 2.70 & 4.60 & 4.15 & 4.1 & 4.24 & 4.12 & 4.96 & 3.34 & 4.25 & 7.68 \\
\hline Total & 7.93 & 6.666 & 10.92 & 5.867 & 13.968 & 5.068 & 9.87 & 17.91 & 8.293 & 38.28 \\
\hline
\end{tabular}

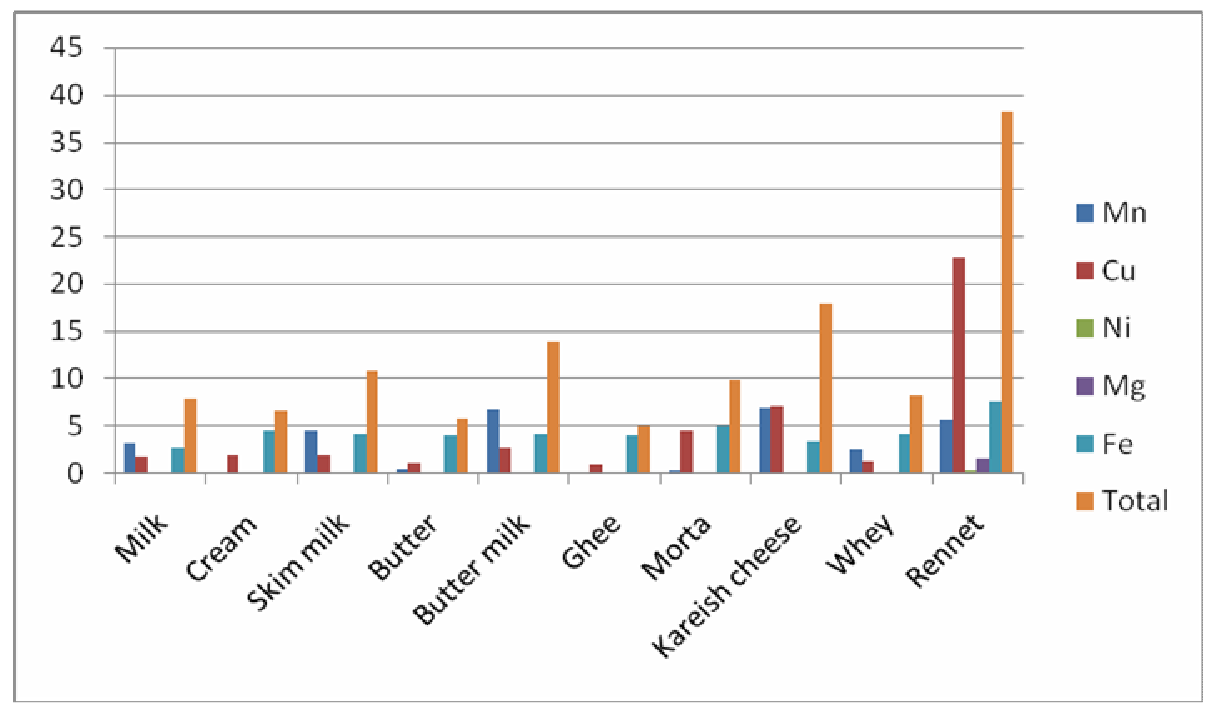

Figure 2: The metals concentration $(\mathrm{mg} / \mathrm{kg})$ in the standards samples. 
Table 4: Percentage $\left(\%^{*}\right)$ of increasing of metals in standards than their corresponding control samples.

\begin{tabular}{ccccccccccc}
\hline Metal & Milk & Cream & $\begin{array}{c}\text { Skim } \\
\text { milk }\end{array}$ & Butter & $\begin{array}{c}\text { Butter } \\
\text { milk }\end{array}$ & Ghee & Morta & $\begin{array}{c}\text { Kareish } \\
\text { cheese }\end{array}$ & Whey & Rennet \\
\hline $\mathrm{Mn}$ & 29.45 & 0.00 & 13.33 & 100.00 & 55.60 & 0.00 & 54.05 & 89.90 & 28.19 & 0.00 \\
\hline $\mathrm{Cu}$ & 60.56 & 49.69 & 66.67 & 11.86 & 78.15 & 8.51 & 54.22 & 86.13 & 28.13 & 0.00 \\
\hline $\mathrm{Ni}$ & 53.33 & 62.50 & 65.00 & 28.57 & 77.27 & 0.00 & 100.00 & 45.83 & 58.04 & 0.00 \\
\hline $\mathrm{Mg}$ & 50.00 & 38.46 & 80.00 & 50.00 & 38.93 & 85.00 & 86.67 & 79.38 & 46.67 & 0.00 \\
\hline $\mathrm{Fe}$ & 20.74 & 46.30 & 21.69 & 38.05 & 6.84 & 5.09 & 34.48 & 51.19 & 44.71 & 0.00 \\
\hline $\mathrm{Total}$ & 34.05 & 47.46 & 27.75 & 37.96 & 45.47 & 5.86 & 44.44 & 80.49 & 37.22 & 0.00 \\
\hline
\end{tabular}

$\% *=100-($ Cont. / Stand. $\times 100)$

Cont. $=$ The metals concentration $(\mathrm{mg} / \mathrm{kg})$ in the control samples

Stand. $=$ The metals concentration $(\mathrm{mg} / \mathrm{kg})$ in the standards samples

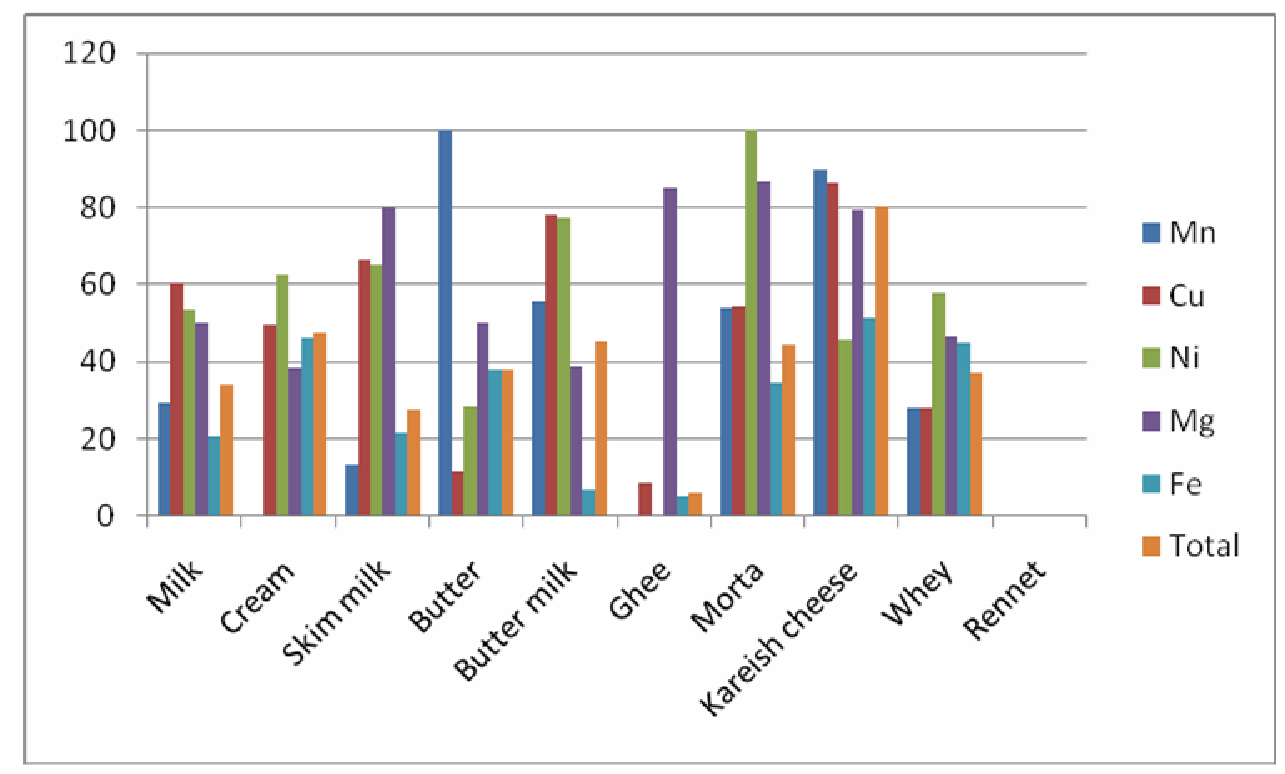

Figure 3: Increasing metals $\%$ in standards than their corresponding control samples.

\section{DISCUSSION}

Before throwing the lights towards the residue behavior of the examined metals in the manufactured milk products, there is a question: Are the studied metals in the initial milk (control milk sample) came in the acceptable limits? Unfortunately, the values of $\mathrm{Mn}, \mathrm{Cu}$ and $\mathrm{Fe}$ were found to exceed the recorded limits of IDF (International Dairy Federation), and also higher than the recorded results of Abou-Arab (1991), Florea et al. (2006), Birghila et al. (2008) and Enb et al. (2009) as mentioned in Table 1. While, ElPrince and Sharkawy (1999) found higher level of $\mathrm{Cu}$ in buffalo's milk than our obtained result. Higher levels of $\mathrm{Fe}$ and $\mathrm{Ni}$ than our obtained results were recorded by 
Ogabiela et al. (2011) as they found Fe (5.99 and $3.24 \mathrm{mg} / \mathrm{L}$ ) and $\mathrm{Ni}(3.013$ and 2.097 $\mathrm{mg} / \mathrm{L}$ ) in 2 regions of Nigeria (Kano and Zaria), respectively. Ogabiela et al. (2011) mentioned that their results of $\mathrm{Fe}$ were within the recommended daily allowance $(15 \mathrm{mg}$ by Durdana et al., 2007).

High levels of heavy metals in this study may be attributed to the high contamination of animal feed and water by such pollutants and could be excreted into milk at various levels (Abou-Arab et al., 1994; Abou-Arab, 1997) and also may be reached to milk through handling procedures.

The distribution patterns of the studied metals in the examined buffalo's milk and derived milk products (control samples) were recorded in Table 2 and Figure 1, and the distribution patterns for the standard samples were recorded in Table 3 and Figure 2. A question arises: why standard samples were used in this investigation? The answer is to add a more metals content to the control samples to give a clearer view about the residues behavior of the studied metals. Thus, the interpretation may be more obvious if a known amount of metals is added to the control samples. Furthermore, the percentages of increase of metals content in the standards samples more than their corresponding control samples can be calculated as shown in Table 4 and Figure 3.

With attention to the residue behavior of manganese $(\mathrm{Mn})$, It was found that $\mathrm{Mn}$ disappeared from the fat concentrated milk products starting from cream to butter and finally by ghee, while it concentrated in their by-products skim milk $(3.9 \mathrm{mg} / \mathrm{kg})$, butter milk $(3.01 \mathrm{mg} / \mathrm{kg})$ than the initial control milk sample $(2.3 \mathrm{mg} / \mathrm{kg})$. Although butter was manufactured from cream and cream had no detectable contents of $\mathrm{Mn}, \mathrm{Mn}$ was concentrated in butter milk than the initial control milk sample. When manufacturing Kareish cheese; Mn was concentrated in whey more than in Kareish cheese (Table 2 and Figure 1). The results of the standard samples were in accordance with the control ones except for butter and Kareish cheese. Although $1 \mathrm{mg} / \mathrm{kg}$ of $\mathrm{Mn}$ was added to the standard milk sample over its original content of $2.3 \mathrm{mg} / \mathrm{kg}$, standard cream and standard ghee had no detectable amount of $\mathrm{Mn}$; and it concentrated in standard skim milk (4.5 $\mathrm{mg} / \mathrm{kg})$ and standard butter milk $(6.78 \mathrm{mg} / \mathrm{kg})$ (Table 3 and Figure 2). This obtained results of residue behavior of $\mathrm{Mn}$ in standard cream and ghee confirmed those of the control ones. Therefore, percentage of increasing of $\mathrm{Mn}$ in the standard samples than their corresponding control ones (Table 4 and Figure 3), showed $0.00 \%$ increase in cream and ghee. Thus, it can be concluded that, Mn residues were not concentrated in the fat concentrated milk products.

With regards to copper $(\mathrm{Cu})$ content, it was concentrated in cream and butter. For nickel (Ni), it disappeared in ghee but concentrated in Kareish cheese (Table 2 and Figure 1); and the standard samples confirmed this result (Table 3 and Figure 2), in addition, it concentrated in skim milk and butter milk.

When through the light towards magnesium $(\mathrm{Mg})$ residue behavior, standard skim milk and standard Kareish cheese showed obvious concentration than corresponding control ones (Table 3 and Figure 2), therefore, Table 4 and Figure 3 showed 80.00 and $79.38 \%$ increasing of $\mathrm{Mg}$ in standard skim milk and standard Kareish cheese, respectively, than control ones. For iron (Fe), it was concentrated in skim milk, butter milk, whey, i.e. by-products. Also total metals content was more concentrated in by-products skim milk, butter milk and whey, although the milk products cream, butter and ghee contained more total metals content than the initial milk sample (Table 2 and Figure 1). In butter, the total metals levels were concentrated by 0.69 fold as compared to initial milk, and 1.04 fold as compared to cream. In the study of Enb et al. (2009), higher levels of metals concentration were recorded than the present study as they found metals levels in buffalo's butter were concentrated by 5.6-7.7 folds as compared to initial milk, and 1.4-1.6 folds as compared to cream. Abou-Arab (1991) obtained similar results of Enb et al. (2009) who reported that, metals concentrated in cream. 
In the examined study, ghee contained total metals content more than butter and cream; and consequently more than initial milk. The concentrated factors of the total metals in ghee were 0.91 fold than that in initial milk, and 1.36 fold than that in cream, and 1.31 fold than that in butter. Enb et al. (2009) found higher levels of metals concentration in ghee in comparison to the present study as they found buffalo's samna (ghee) contained concentrated metals $6.7-9.2$ folds than that in initial milk, and 1.6-1.8 folds than that in cream; while 1.1-1.2 folds than that in butter was lower in comparison to the present investigation.

Concerning the examined manufactured Kareish cheese, results in Table 2 indicated that all the examined metals were detected but the total metals content $(3.493 \mathrm{mg} / \mathrm{kg})$ was lower than in initial milk $(5.23 \mathrm{mg} / \mathrm{kg})$ as the reduction level in Kareish cheese was 1.49 fold than in initial milk.

In conclusion, $\mathrm{Mn}$ was found to disappear from fat concentrated milk products (cream, butter and ghee), while concentrated in their by-products. $\mathrm{Cu}$ concentrated in cream and butter. $\mathrm{Ni}$ disappeared in ghee but concentrated in Kareish cheese. No obvious concentration of $\mathrm{Mg}$ in milk products while Fe concentrated in by-products skim milk, butter milk and whey. Although milk products contained more total metals content like in cream, butter and ghee more than in the initial milk, the total metals content was more concentrated in by-products like in skim milk, butter milk and whey. But in case of Kareish cheese, it contained total metals content lower than in initial milk.

\section{REFERENCES}

Abou-Arab, A.A.K. (1991): Microbiological and compositional quality of dairy products in relation to some pollutants. Ph.D. Thesis, Faculty of Agriculture, Ain-Shams University.

Abou-Arab, A.A.K. (1997): Effect of Ras cheese manufacturing on the stability of DDT and its metabolites. J. Food Chem. 59(1): 115-119.
Abou-Arab, A.A.K.; Kholif, A.M. and Abou El-Nor, S.A.H. (1994): Effect of spraying diazinon to control the external parasites on the productive performance of dairy animals. 3. Minerals contents of blood serum and milks.

Ahmed, W.M.S. (2002): Studies on heavy metal pollution farms in relation to production performance. Ph.D. Thesis Fac. Vet. Med. Zag. University.

Birghila, S.; Dobrinas, S.; Stanciu, G. and Soceanu, A. (2008): Determination of major and minor elements in milk through ICP-AES. Environmental Engineering Management J. 7 (6): 805-808.

Carl, M. (1991): Heavy metals and other trace elements. Monograph on residues and contaminants in milk and milk products. Special Issue 9101, pp.: 112119. International Dairy Federation "IDF", Belgium.

Durdana, R.H.; Shahnaz, I. and Shaikh, G.H. (2007): Assessment of the levels of trace metals in commonly edible vegetables locally available in the markets of Karachi city. Pak. J. Bot. 39(3).

Eckles, C.H.; Combss, W.B. and Macy, H. (1951): Milk and milk products. $4^{\text {th }}$ ed. pp.: 237. Mc. Grow-Hill Book Company, Inc.

El-Batanouni, M.M. and Abo-El-Ata, G. (1996): Metals in food. Conference on Food-borne contamination and Egyptian's Health, Fac. of Agri. Mansoura, 26-27 November, pp.: 11-25.

El-Prince, Enas and Sharkawy, A.A. (1999): Estimation of some heavy metals in bovine milk in Assiut governorate. Assiut Vet. Med. J. 41(81): 153-169.

El-Sadek, G.; Khalafalla, S. and Shehata, A. (1972): Tests of manufacture of milk and milk products "In Arabic" Publications of Faculty of Agriculture, Ain-Shams University, Cairo.

Enb, A.; Abou Donia, M.A.; Abd-Rabou, N.S.; Abou-Arab, A.A.K. and El-Senaity, M.H. (2009): Chemical composition of raw milk and heavy metals behavior 
during processing of milk products. Global Veterinaria, 3(3): 268-275.

Farid, S.M.; Enani, M.A. and Wajid, S.A. (2004): Determination of trace elements in cow's milk in Saudi Arabia. JKAU: Egn. Sci. 15(0-2): 131-140.

Florea, T.; Huszti, S.O. and Costin, G.M. (2006): Heavy metal contaminants in milk and cheese. The Annals of the University Dunarea de Jos of Galati, Fascicle VI-Food Technology, pp.: 26-32.

Gossel, T.A. and Bricker, J.D. (1990): Principles of Clinical Toxicology. $2^{\text {nd }}$ ed., Raven Press Ltd. New York.

$I D F$, (1979): International Dairy Federation Bulletin, Chemical Residues in milk and milk products. I.D.F. Document, 133.

Jones, T.C. and Hunt, R.D. (1983): Veterinary Pathology. $5^{\text {th }}$ ed., Lea and Fibiger, Philadelphia (USA).

Koh, T.S. and Judson, G.T. (1986): Trace elements in sheep grazing near a leadzinc smelting complex at Port Pirie South Australia. Bulletin of Environmental Contamination and Toxicology, 37: 87-95.

Kolmer, J.A.; Spaudlding, E.H. and Robinson, H.W. (1951): Approved laboratory techniques. New York: Appleton Century Crafts, pp.: 10901091.

Lee, R.V. and Garvey, G.J. (1998): Copper. In: Harbison, R.D. (Ed.): Hamilton \& Hardy's industrial Toxicology. $5^{\text {th }}$ ed., pp.: 59-92.

Licata, P.; Trombetta, D.; Cristani, M.; Giofre, F.; Martino, D. and Calo, M. (2004): Levels of "toxic" and "essential" metals in samples of bovine milk from various dairy farms in Calabria, Italy. Environ. Int. 30: 1-6.

Mertz, W.ED. (1986): Trace elements in human and animal nutrition, vol. I and II, $5^{\text {th }}$ ed. Academic Press, New York.

Ogabiela, E.E.; Udiba, U.U.; Adesina, O.B.; Hammuel, C.; Ade-Ajayi, F.A.; Yebpella, G.G.; Mmereole, U.J. and Abdullahi, M. (2011): Assessment of metal levels in fresh milk from cows grazed around Challawa industrial estate of Kano, Nigeria. J. Basic. Appl. Sci. Res. 1(7): 533-538.

Ogabiela, E.E.; Yebpella, G.G.; Ade-Ajayi, A.F.; Mmereole, U.J.; Ezeayanaso, C.; Okonkwo, E.M.; Ahola, D.O.; Udiba, U.U.; Mahmood, A. and Gandu, I. (2010): Determination of the level of some elements in edible oils sold in Zaria, northern Nigeria. Global J. Pure Appl. Sci. 6(3): 325-331.

Okada, I.A.; Sakuma, A.M.; Maio, F.D.; Dovidauskas, $S$. and Zenebon, $O$. (1997): Evaluation of lead and cadmium levels in milk due to environmental contamination in Paraiba valley region of South-Eastern Brazil. Revista-deSaude-Publica, 31 (2): 140-143.

Pennigton, J.A.; Schoen, S.A.; Salmon, G.D.; Young, B.; Johnson, R.D. and Marts, R.W., (1995): Composition of core foods of the US Food Supply, 19821991. J. Food Compos. Anal. 8: 171-217.

Sarkar, B.; Laussac, J.P. and Lau, S. (1983): Transport forms of copper in human serum. In: Sarkar, B. (Ed.): Biological aspects of metals and metal-related diseases. New York: Raven Press Ltd., pp.: 23-40.

Schroeder, H.A. (1973): The trace elements and nutrition. London: Faber and Faber.

Schuhmacher, M.; Borques, A.M.; Domingo, L.J. and Carbella, J. (1991): Dietary intake of lead and cadmium from foods in Tarragona Province, Spain. Bulletin of Environmental Contamination and Toxicology, 46: 320-328.

Somer, E. (1974): Toxic potential of trace metals in foods. A review J. Food Sci. 39: $215-217$.

Steijns, J.M. (2001): Milk ingredients as nutraceuticals. Int. J. Dairy Technol. 54: 81-88.

Tripathi, R.M.; Raghunath, R. and Krishnamoorthy, T.M. (1997): Dietary intake of heavy metals in Bombay city, India. Sci. Total Environ. 208: 49 - 159. 
Ukhun, M.E.; Nwazote, J. and Nkwocha, F.O. (1990): Level of toxic mineral elements in selected foods marketed in Nigeria. Bull. Environ. Contain-Toxicol. 44: 325-330.

Venugopal, B. and Luckey, T.D. (1978): Metal toxicity to mammals, vol. II. Chemical toxicity of metals and metalloids. Plenum Press, New York.

Watson, D.H. (2001): Food Chemical Safety. Watson D.H. (Ed), CRC Press Boca Raton FL, vol. 1: 1-12.
WHO, (1973): World Health Organization. Trace elements in human. Who Technical Report Series, No. 532, WHO, Geneva.

Yahaya, M.I.; Ezor, G.C.; Musa, Y.F. and Muhamad, S.Y. (2010): Analysis of heavy metals concentration in road side soils in Yauri, Nigeria. African J. Pure Appl. Chem. vol. 4(3). 